\title{
Traslado de edificios históricos. El caso de León durante la etapa franquista
}

\author{
Emilio Morais Vallejo \\ Universidad de León
}

\begin{abstract}
RESUMEN. El traslado de edificios históricos es una práctica no recomendada por la teoría restauradora y la legislación derivada de ella, debido al peligro que supone para la integridad de los valores documentales, históricos y artísticos de los monumentos. No obstante, fue una modalidad utilizada durante el franquismo, y prueba de ello son los cuatro traslados realizados en la ciudad de León entre 1945-1965. Con los elementos más representativos de los monumentos se levantaron edificios nuevos con formas y funciones distintas a las originales.

Palabras clave: Arquitectura, restauración, conservación, traslado de monumentos, franquismo.

ABSTRACT. The transfer of historical buildings is a practice not recommended by the restoration theory and the legislation derived from it, due to the danger that supposes for the integrity of the documental, historical and artistic values of the monuments. However, it was a common practice under franquism, as evidenced by the four transfers done in the town of Leon between 1945-1965. Representative elements of the original monuments were used to create new buildings with completely different forms and functions.

Key words: Architecture, restoration, preservation, removal of monuments, franquism.
\end{abstract}

Entre los cometidos propios de los historiadores del arte están el análisis histórico y la crítica de las intervenciones realizadas en los monumentos con motivo de su restauración o conservación ${ }^{1}$. Esta labor no sólo ha de tener una intención historicista -útil para la elaboración de un panorama global de la historia de la

\footnotetext{
${ }^{1}$ Entendemos por monumento la definición dada por la Convención para la salvaguarda del patrimonio arquitectónico de Europa, Granada, 1985: los monumentos son todas las realizaciones especialmente relevantes por su interés histórico, arqueológico, artístico, científico, social o técnico, comprendidas las instalaciones o los elementos decorativos que constituyen parte integrante de estas realizaciones.
}

restauración, donde se recojan los distintos tipos de intervenciones y se analice su relación con el contexto en el que se hicieron- sino que también ha de servir como medio para desarrollar criterios que sean de utilidad para otras intervenciones. Con este objetivo analizamos cuatro intervenciones concretas, llevadas a cabo en León durante un periodo relativamente amplio (1945-1975), que pueden ser consideradas como ejemplo significativo de una peculiar manera de entender la intervención conservadora en los monumentos, inserta en unas coordenadas políticas y culturales muy precisas. Aunque se conoce bastante bien los orígenes de la 
restauración monumental en España y el intervalo 1900-1936, son todavía muy escasos los estudios referidos a la etapa franquista, por eso consideramos conveniente aportar ejemplos que vayan clarificando las actuaciones de dicho período².

En esta ocasión trataremos el traslado de monumentos, modalidad de actuación que significa sacar de su ambiente a un edificio, aquél para el cual fue creado, e introducirlo en otro ajeno y distante en el espacio, en el que resulta extraño. A su vez se altera éste con un elemento foráneo que distorsiona su trama esencial, no siempre para mejorarla, sin lograr casi nunca un buen acoplamiento. Se trata de un tipo de intervención drástica, sobre todo si tenemos en cuenta que por lo general el edificio primitivo sufre alteraciones importantes en su fisonomía, de tal manera que nunca vuelve a ser el mismo y se destruye gran parte de su legado histórico, amén de otras consideraciones artísticas. Aunque la restauración, como dice acertadamente Antón Capitel, es un campo ambiguo, oscuro y variable, lleno de contradicciones ${ }^{3}$, sin embargo prácticamente todas las teorías, así como los textos legales

\footnotetext{
${ }^{2}$ A. HERnÁndez MARTíneZ, “¿Qué hace una chica como tú en un sitio como éste?. (Algunas reflexiones acerca de la relación entre la Historia del Arte y el Patrimonio Cultural)", Artigrama, 2000, no 15 , p. 549550. En este trabajo se hace una interesante síntesis de la historiografía de la restauración en España, dejando patente la escasez de referencias al período franquista. También en P. NAVASCUÉS PALACIO, "La restauración de monumentos en España: aproximación bibliográfica (1954-1994)", en Historiografía del Arte Español en los siglos XIX y XX. VII ${ }^{a}$ Jornadas de Arte, Madrid, 1995, pp. 77-88. De la misma manera es muy escasa la historiografía específica de interés sobre la arquitectura del franquismo, como recoge C. ÁlvAREZ QUINTANA, "El compromiso del historiador del Arte con la arquitectura española en la etapa franquista (1940-1975)", en Actas del Simposio: El Historiador del Arte, hoy, Soria, 1997, pp. 133-141.

${ }^{3}$ A. CAPITEL, Metamorfosis de monumentos y teorías de la restauración, Madrid, 1988, p. 12.
}

emanados de ellas, están de acuerdo en que no se debe trasladar los monumentos; siempre se exhorta a su permanencia, e incluso de sus partes, en la ubicación primitiva. Sólo se permite contravenir esta doctrina en casos muy extremos, cuando queda demostrado fehacientemente que otras actuaciones son totalmente inviables.

En los cuatro casos seleccionados veremos edificios al final de su ciclo vital, los cuales fueron desmantelados, trasladados en parte y reconstruidos con una forma nueva, para terminar siendo lo que nunca fueron, desvirtuada su fisonomía, su lenguaje arquitectónico y su significado más íntimo, así como adulterado su valor artístico original. Desde los albores de la restauración se viene considerando que los monumentos nos proporcionan valiosas informaciones sobre la sociedad que los hizo posibles y sobre los hombres que los utilizaron; si se destruyen o se desfiguran los rastros que nos permiten la recuperación del pasado, el monumento pierde gran parte de su valor ${ }^{4}$. Al mismo tiempo, todo monumento histórico es también un monumento artístico, por lo que exige

\footnotetext{
${ }^{4}$ Esta es la base de las primeras teorías de la restauración moderna, tanto la Científica de Boito (1836-1914) y Giovannoni (1873-1947), como la Histórica de Beltrami (1854-1933). Para el análisis más detallado de estas teorías se debe consultar C. CESCHI, Teoría e storia del restauro, Roma, 1970, pp. 107-114. También el tema ha sido tratado por autores españoles, A. M. MACARRóN Miguel, Historia de la conservación y la restauración desde la antigüedad hasta finales del siglo XIX, Madrid, 1995; A. M. MACARRÓN Miguel y A. GonzÁlez MozO, La conservación y la restauración en el siglo XX, Madrid, 1998; M. J. MARTÍNEZ JUSTICIA, Historia y teoría de la conservación y restauración artística, Madrid, 2000; I. GONZÁLEZ VARAS, Conservación de bienes culturales. Teoría, historia, principios y normas, Madrid, 1999; J. RIVERA, "Restauración arquitectónica desde los orígenes hasta nuestros días. Conceptos, teoría e historia”, en Teoría e Historia de la restauración, 1997, pp. 103-170.
} 
respeto a su integridad y a su carácter y sentido primario ${ }^{5}$.

Por todas estas razones, antes de abordar cualquier tipo de intervención, se ha realizar un estudio histórico-artístico de la obra en cuestión, como proceso previo e imprescindible. Desgraciadamente esta prác-tica, desde todos los puntos de vista necesaria para la protección del patrimonio cultural, nunca, hasta ahora, estuvo suficientemente considerada en España, casi siempre fue excepcional $\mathrm{y}$, lo que es peor, no había conciencia de su utilidad 6 . Como veremos, esta cuestión fue determinante en las actuaciones llevadas a cabo durante la etapa franquista, ya que los informes que acompañaban los proyectos, cuando existían, no eran verdaderos estudios documentados, sino meros trámites sin análisis rigurosos. No se tuvo en cuenta que desde principios del siglo $X X$ las cartas de restauración se preocupaban de exigir análisis previos a cualquier intervención, por considerarlo de total necesidad?

5 A. RIELG, El culto moderno a los monumentos, Madrid, 1999 (1ª ed. Viena 1903), pp. 24-25.

${ }^{6}$ El tema lo aborda C. FONTEla SAN JUAN, "La Historia del Arte, una ciencia al servicio del conocimiento del monumento", en Arte e Identidades Culturales, Actas del XII Congreso Nacional del CEHA, Oviedo, 1998, pp. 452-459; ÍDEM, "El historiador del arte ante una actuación en el patrimonio construido", en Actas del Simposio El Historiador del Arte, hoy, Soria, 1997, pp. 165- 173; A. GoY DIZ, "El papel del historiador del Arte en la conservación del patrimonio construido como conciencia cultural del pasado histórico del pueblo", en Actas del Simposio El Historiador del Arte, hoy, Soria, 1997, pp. 175-184.

7 Extractamos algunos textos referentes a este tema, tomados de Martínez Justicia, M. J., Antología de textos sobre restauración. Selección, traducción y estudio crítico, Jaén, 1996:

p.166. Carta del Restauro de 1932, art. 11: en la restauración de los monumentos debe ser condición esencial y taxativa que una documentación precisa acompañe los trabajos mediante informes analíticos
Durante las primeras décadas del siglo XX hubo en España un interesante debate entre la escuela Conservadora, partidaria de mantener los edificios en su estado, respetando al máximo todos los detalles originales que el tiempo ha ido dejando, y la escuela Restauradora, que justificaba la supresión de añadidos y la fabricación de elementos nuevos para sustituir los desaparecidos, imitando el estilo inicial ${ }^{8}$. En la fructífera controversia cada una de las facciones, alegando fundamentaciones especulativas y llevando a cabo las intervenciones según éstas, tuvo personajes relevantes en su defensa. Amós Salvador y Vicente Lámperez, abogaban por la segunda teoría, entendida a la manera de Viollet-le-Duc ${ }^{9}$, mientras que en el bando contrario Leopoldo Torres Balbás, teórico y práctico de la conservación, era el más cualificado representante de la tendencia mayoritaria en la Europa de aquellos momentos. La guerra civil y el sistema político surgido de ella paralizaron el desarrollo de las nuevas teorías, retomándose las posturas más tradicionalistas y

p. 65. Carta de Venecia, 1964, art.: la restauración estará siempre precedida y acompañada de un estudio arqueológico e histórico del monumento.

p. 174. Carta del Restauro, 1972, art.8: toda intervención debe ser estudiada previamente $y$ argumentada por escrito... Anexo B: ...La redacción del proyecto de restauración de una obra arquitectónica debe estar precedida de un estudio atento del monumento, elaborado desde distintos puntos de vista (que tenga en cuenta su posición en el contexto territorial $o$ en el tejido urbano, los aspectos tipológicos, las apariencias y cualidades formales, los sistemas y caracteres constructivos, etc.) tanto en relación con la obra original, como también a los posibles añadidos y modificaciones. Parte integrante de este estudio serán las investigaciones bibliográficas, iconográficas, archivo, etc., para recabar todos los datos históricos posibles.

p. 107. Declaración de Amsterdam, 1975, art. 8: todo programa de rehabilitación deberá ser estudiado a fondo antes de su ejecución.

${ }^{8}$ M. J. MARtínez Justicia, Historia y teoría..., p. 312.

9 E. VIOLleT-LE-DUC, Dictionaire raisonné de l'architecture française, du XIe au XVIe siècle, París, 1866. 
neohistoricistas, síntoma de un claro retroceso, que tuvieron graves repercusiones para el campo restaurador ${ }^{10}$. En el franquismo la polémica desapareció porque el régimen optó decididamente por la tendencia restauradora, hasta el punto de involucrar la ideología política en su defensa, no dejando ninguna opción a la controversia ${ }^{11}$. Por esta razón tampoco hubo un especial interés de arquitectos y historiadores del arte por la teorización. $\mathrm{Si}$, como se ha dicho en repetidas ocasiones, un edificio es un testimonio donde quedan impresas las huellas de las sociedades que pasaron por él, las que dejaron los restauradores de la etapa que nos ocupa son elocuentes del momento cultural del período franquista.

Pocos arquitectos se salvan de la generalización apuntada, pudiendo destacarse entre ellos a Luis Menéndez Pidal ${ }^{12}$, a quien traemos aquí a colación por ser claro representante del quehacer conservador de la época, además de haber realizado varios trabajos de envergadura en la provincia de

-

10 I. ORDIERES DíEZ, Historia de la restauración monumental en España (1835-1936), Madrid, 1995, p. 157; M. J. MARTíNEZ JUSTICIA, Historia y teoría..., p. 323

11 A. LLORENTE, Arte e ideología en el franquismo (1936-1951), Madrid, 1995 p. 68, explica que durante la posguerra la arquitectura fue entendida como una actividad política, por lo que no resultaba extraño que la Dirección General de Arquitectura formase parte del Ministerio de la Gobernación, como medio más eficaz de controlar y dirigir las realizaciones arquitectónicas.

12 La teoría de L. MenÉndez PIDAL sobre la intervención en monumentos queda recogida en el discurso leído con motivo de su recepción en la Real Academia de Bellas Artes de San Fernando, en 1956, titulado El arquitecto y su obra en el cuidado de los monumentos. No se puede considerar que aporte muchas novedades, recogiendo los principales fundamentos de la restauración conservadora y haciendo hincapié en la investigación previa a la intervención, así mismo defendía la conservación del entorno del monumento, oponiéndose al desmontaje de los monumentos por los daños irreparables que se podrían producir. En sus intervenciones prácticas no siempre siguió sus propios principios teóricos.
León, por lo que podemos estimar que influyó directamente en el quehacer de los arquitectos leoneses de aquellos años ${ }^{13}$.

A la hora de decidir sobre el traslado de un edificio lo primero que se debe plantear es su licitud. Todas las teorías restauradoras que se han preocupado del tema han mostrado su oposición al trasplante de edificios, y las legislaciones se han hecho eco de ello prohibiéndolo salvo en casos muy excepcionales.

En la Carta de Atenas de 1931 la prohibición para trasladar edificios queda implícita al afirmar que, en el caso de que una restauración resulte indispensable como consecuencia de degradaciones o destrucciones, recomienda respetar la obra histórica y artística del pasado sin proscribir el estilo de cada época... el traslado de las obras del lugar para el que fueron creadas, como principio, debe considerarse inoportuno ${ }^{14}$.

En las Istruzioni per il Restauro dei Monumenti de 1938, el artículo 7 dice que debe excluirse categóricamente, como arbitrario, el traslado de edificios monumentales, la alteración del ambiente monumental, conservado en su forma original 15 .

Más claro se expuso en el art. 7 de la Carta de Venecia de 1964: un monumento no puede ser separado de la historia de la que es testimonio, ni del ambiente en el que se encuentra. Por lo tanto, el cambio de una parte o de todo el monumento no puede ser tolerado más

${ }^{13}$ En León comenzó su vida profesional, donde desempeñó el cargo de arquitecto municipal y más tarde de la Diputación Provincial y de la Diócesis de Astorga. Intervino, entre otras obras, en la restauración de la catedral, San Isidoro, la Colegiata de Arbas, San Tirso de Sahagún, el castillo de Valencia de Don Juan y en el puente de Hospital de Órbigo.

${ }^{14}$ M. J. Martínez Justicia, Antología de textos..., p. 58 y 60.

15 Recogido en C. CESCHI, Teoria e storia del restauro..., p. 214. 
que cuando la salvaguardia de un monumento lo exija, o cuando esté justificado por causas de relevante interés nacional o internacional ${ }^{16}$.

La misma rotundidad se mantiene en foros, documentos y normativas sucesivos, pudiendo servir de ejemplo la Carta del Restauro de 1972, que prohíbe las remociones, reconstrucciones o traslados a emplazamientos diferentes de los originales, a menos que no esté determinado por razones superiores de conservación ${ }^{17}$.

Como resumen de todo lo dicho puede servir la opinión de Cesare Brandi: Es absolutamente ilegítimo el desmantelamiento y recomposición de un monumento en un lugar diferente de aquel donde fue realizado. El monumento, desmontado y reconstruido en otro lugar, se degrada, siendo un falso de sí mismo. Sólo es legítimo el desmantelamiento y recomposición cuando no se pueda conseguir su salvación de otro modo, pero siempre y sólo en relación con el lugar histórico donde fue construido ${ }^{18}$.

Algunos teóricos españoles del momento que aquí nos interesa mostraron su opinión contraria a la remoción de edificios. Es el caso del citado Luis Menéndez Pidal, quien era partidario de mantener a toda costa los edificios en el ambiente y paisaje local para los que fueron concebidos ${ }^{19}$, además de defender la diferenciación de las partes nuevas añadidas, sólo admisibles en casos excepcionales ${ }^{20}, \mathrm{y}$ 65.

${ }^{16}$ M. J. Martínez Justicia, Antología de textos..., p.

17 Ídem, p. 173.

18 C. BRANDI, Teoría de la Restauración, Madrid, 1999 (1ª ed., Roma, 1963), p. 78.

${ }^{19}$ L. MÉNDEZ PIDAL, El arquitecto y su obra en el cuidado de los monumentos, Madrid, 1956, p. 29.

20 ÍDEM, p. 37. de preferir la ruina total de un monumento a una equivocada intervención ${ }^{21}$.

Tampoco la legislación española ha sido partidaria del traslado de monumentos. La ley de 1933, una buena ley que trascendió el período de la República en que fue promulgada' ${ }^{22}$, así como su ulterior adaptación durante el franquismo, proclamaban: se proscribe todo intento de reconstrucción de los monumentos, procurándose por todos los medios de la técnica su conservación y consolidación, limitándose a restaurar lo que fuera absolutamente indispensable y dejando siempre reconocibles las adiciones ${ }^{23}$. La legislación posterior mantuvo las mismas tesis, así por ejemplo la Ley de Patrimonio Histórico de 1985 dice en el artículo 18: un inmueble declarado Bien de Interés Cultural es inseparable de su entorno. No se podrá proceder a su desplazamiento o remoción, salvo que resulte imprescindible por causa de fuerza mayor o de interés social ${ }^{24}$.

Sin necesidad de acudir a más ejemplos, que nos alejarían de las fechas predeterminadas, podemos concluir que tanto la teoría como la legislación, están y estuvieron siempre en contra de las traslaciones. Como es natural, es habitual una apostilla para consentir traslados concretos, pero sólo cuando existan causas excep-

${ }^{21}$ ÍDEM, p. 57.

22 En su cincuentenario hubo una exposición conmemorativa, acompañada de estudios que analizaban su historia, contenido y validez, recogidos en 50 años de protección del Patrimonio histórico-artístico, 1933-1983, Madrid, 1983, destacando: M. FERNÁNDEZMIRANDA, "Cincuenta años", pp. 7-10; L. JIMÉNEZClAVERÍA, "Algunos aspectos de la protección jurídica del Patrimonio Arquitectónico español”, pp. 11-16

${ }^{23}$ Ley de 13 de mayo de 1933, modificada por la de 22 de diciembre de 1955 sobre defensa, conservación y acrecentamiento del patrimonio histórico-artístico nacional, La Gaceta, 25 de mayo de 1933, y BOE de 25 de diciembre de 1955, art. 19.

${ }^{24}$ Ley 16/1985 de 25 de junio, BOE de 29 de junio de 1985, art. 18. 
cionales de fuerza mayor que los hagan inevitables. Para explicar esto se suele acudir a la Recomendación sobre la conservación de los bienes culturales que la ejecución de obras públicas o privadas pueda poner en peligro, adoptada por la Conferencia General de París de 1968, con ocasión de la construcción de la presa de Asuán, que obligó al traslado de los edificios amenazados por las aguas. Pero incluso aquí se aboga por la conservación in situ y la recolocación en lugares que asemejen la ubicación primitiva y sus vinculaciones naturales, históricas o artísticas ${ }^{25}$. Con motivo de la construcción de embalses, en España se hicieron algunos traslados de monumentos, siendo el primero la iglesia de San Pedro de la Nave, en 1931, trasplantado totalmente para reubicarle en un lugar próximo. Otros ejemplos destacados fueron los realizados al iniciarse los embalses del río Miño, que determinaron el traslado de varias iglesias ${ }^{26}$. El arquitecto encargado de estos trabajos, F. Pons Sorolla, consciente del peligro que corren los monumentos en estas ocasiones, por la radical transformación y falseamiento que conlleva, se mostraba contrario a cualquier traslado, sólo aceptable en casos de fuerza mayor que tuvieran que ver con intereses de importancia nacional, como creía que eran estos ${ }^{27}$.

25 A. M. Macarrón Miguel y A. GonZÁlez MOZO, ob. cit., p. 158.

${ }^{26}$ Las iglesias de S. Juan de Coba, S. Esteban de Chouzán, iglesia de S.Juan de Puertomarín.

${ }^{27}$ Sus tesis y justificaciones las defiende en F. PONS SOROLLA, "Traslados de monumentos en España. Puertomarín”, Arquitectura, no 36, Madrid, 1961, pp. 1725. Considera siempre condenable cualquier traslado porque se modifican las circunstancias técnicas, geográficas e históricas. Además recuerda que el monumento no es sólo aspecto, sino también traza, materiales, asiento de sillares, composición del mortero, cimentación, etc.; con el traslado se pierde la historia científica del monumento. Por estas razones aconseja el máximo de fidelidad cuando el trasplante sea inevitable, tanto con la forma primigenia como con
Una vez decidido el traslado, el mayor peligro para la integridad del monumento es la manera de realizarlo. Por lo tanto, la segunda cuestión consiste en establecer las oportunas comparaciones entre el edificio primitivo y su réplica, para determinar hasta que punto la reconstrucción fue un verdadero y simple transplante o una transformación artificiosa. Ya en 1883 Camilo Boito, con motivo del Congreso de arquitectos e ingenieros civiles celebrado en Roma, estableció ocho normas específicas para que en las reconstrucciones se evitara en lo posible el falso histórico ${ }^{28}$.

Cuando se plantea cualquier restauración, una de las cuestiones más espinosas es el peligro que siempre se corre de adulterar el legado intrínseco al edificio, ya que, sino se utilizan los criterios correctos, se puede cometer tanto una falsificación histórica como una falsificación artística ${ }^{29}$. En ambos casos se evaporaría no sólo el significado del monumento, sino también su comunión con la sociedad; por esta razón es significativo que en el prólogo de la Carta de Venecia se encomiende encarecidamente a la humanidad el deber de transmitir las obras monumentales en su completa autenticidad ${ }^{30}$. En todas las restauraciones, del tipo que sean, se reclama el valor de lo auténtico. Esto no quiere decir

\footnotetext{
-

el ambiente que le rodeaba, debiendo ser vigilado por los organismos oficiales y culturales competentes.

28 1. Diferencia de estilo entre lo antiguo y lo moderno. 2 Diferencia de los materiales en su fábrica. 3 Exposición en un lugar contiguo de las partes materiales que se eliminen. 4 Supresión de molduras y decoraciones en las partes nuevas. 5 Marcado con signos convencionales de la parte nueva. 6 Colocación en el monumento de un epígrafe descriptivo de la actuación. 7 Descripción y fotografías de las fases del trabajo. 8 Reconocimiento visual de las acciones realizadas.

${ }^{29}$ C. BRANDI, ob. cit., p. 17.

${ }^{30}$ M. J. MARtínez Justicia, Antología de textos..., p. 63.
} 
que se exija un completo mantenimiento de la originalidad puramente material, sino el mantenimiento de la esencia del monumento; ahora bien, esta esencia se puede mantener aunque se hagan algunas sustituciones materiales durante el proceso de su restauración ${ }^{31}$. Pero lo que no se debe aceptar, con la disculpa de la conservación, es la realización de un fraude histórico o artístico con la modificación material y esencial de la obra, alterando su valor documental, cambiando el elemento significativo $\mathrm{y}$ desvirtuando la originalidad del monumento. Asimismo no debiera servir la coartada de dar funcionalidad a los restos trasplantados de un monumento para perpetrar una adulteración del edificio primigenio.

También se requiere la autenticidad para conservar la conexión de la obra arquitectónica con la sociedad en el seno de la cual surgió, pues el monumento es portador de una determinada identidad cultural, y cualquier tipo de intervención debe asegurar una correcta restauración para que siga aportando testimonios e informaciones de su contexto original, pues no en balde es una fuente histórica de primera magnitud ${ }^{32}$.

La situación llega a su punto más crítico cuando más que una restauración se hace un ejercicio creativo a partir de unos materiales históricos. Esta circunstancia se

31 A. GONZÁLEZ, "Falso histórico o falso arquitectónico, cuestión de identidad", Loggia, nº 1, Valencia, 1996, p. 18, explica que la autenticidad se basa en la esencia y en la peculiaridad del patrimonio. Esencia triple: como documento (histórico, artístico, técnico, arquitectónico, etc.), objeto física $\mathrm{y}$ funcionalmente vivo, y elemento significativo para la comunidad. Peculiaridad doble, derivada de su esencia: un particular concepto de originalidad y el papel que juega la materia.

32 R. GutiérRez, "Las fuentes históricas y la heurística", en Teoría e Historia de la Restauración. I, Madrid, 1997, p. 174. da cuando se utilizan partes de un conjunto monumental para realizar un edificio nuevo, que sólo tiene en común con el primitivo el préstamo de materiales. Pero, al modificarlo sustancialmente, ni la esencia documental, funcional o significativa, ni la presencia figurativa del monumento permanecen en el segundo artefacto. En estos casos se consuma una transformación cualitativa del edificio, no una restitución de la imagen original ${ }^{33}$. Lo que se hace es manipular una entidad previa para hacer otra completamente distinta, con una nueva fisonomía, una nueva función y una nueva significación, sin interesarse ni tan siquiera por la sintaxis primitiva. El objetivo es la conservación a ultranza de fragmentos testimoniales del pasado, pero de esa manera se desprecia no sólo el valor artístico del edificio, sino también el histórico, ese valor que le hace ser un documento útil para la investigación histórica presente o futura, y que por eso hay obligación de mantener, independientemente de que cambie el valor instrumental por una nueva función ${ }^{34}$. Desde las primeras teorías conservadoras del siglo XIX hubo una especial preocupación por las adiciones y las sustituciones, y para paliar sus efectos se recomendaba diferenciar de manera inequívoca lo antiguo de lo nuevo, tanto en materiales como en formas, e incluso con la colocación de paneles explicativos de las modifica-

\footnotetext{
-

${ }^{33}$ R. GIL MiQUEL, "Los límites de la restauración en los objetos antiguos", Anuario del Cuerpo Facultativo de Archiveros, Bibliotecarios y Arqueólogos, Madrid, 1935, denuncia que una intervención demasiado activa, cuyo resultado es excesivamente renovado, debe calificarse de suplantación o de falsificación.

34 A. TrachanA, "Hacia una ética de la restauración", en De varia restauratione. Intervenciones en el patrimonio arquitectónico, Madrid, p. 12, en este sentido afirma que la instancia estética y la instancia histórica tienen que concordar con la instancia de la utilidad.
} 
ciones en un lugar próximo al edificio intervenido ${ }^{35}$.

Por otro lado, la forma más común de actuar es la de mantener las fachadas, o sus partes más notables, edificando tras ellas un interior que nada tiene que ver el original y eliminando la organización arquitectónica que le dio su razón de ser. Actuando así, el monumento se destruye, y lo que queda es una engañosa escenografía ${ }^{36}$.

Tras la Guerra Civil, la restauración en España tomó el rumbo más anticuado apostando por posturas neohistoricistas ${ }^{37}$, bajo cuyo manto se hicieron verdaderas reinvenciones del pasado ${ }^{38}$. Sin embargo las actuaciones no se caracterizaron precisamente por el rigor histórico y científico, sino que con la vuelta hacia las actitudes más tradicionales se ensalzaba la retórica y el monumentalismo por encima y al margen de la veracidad histórica ${ }^{39}$. Se consideraba más importante el carácter representativo del edificio, con el objetivo de adecuarle a las imágenes más queridas de la ideología dominante, el casticismo y el monumentalismo ${ }^{40}$, haciendo gala de una

35 A. M. MACARRÓN Miguel y A. GonZÁlez MOZO, ob. cit., pp 138-139.

36 A. CAPITEL, "Inmueble monumental y forma urbana”, en 50 años de protección del Patrimonio históricoartístico, 1933-1983, Madrid, 1983, p. 22. 157.

${ }^{37}$ I. ORDIERES DíEZ, Historia de la restauración ..., p.

38 Para tener una idea general de la restauración realizada en España durante la etapa franquista se puede consultar: AA. VV., Veinte años de restauración monumental en España. Catálogo de la exposición, Madrid, 1958; AA. VV., Patrimonio monumental de España. Exposición sobre su conservación y revitalización. Catálogo de la exposición, Madrid, 1976; AA.VV. 50 años de protección del Patrimonio Histórico Artístico (1933-1983), Madrid, 1983.

39 A. J. MORALES, Patrimonio histórico-artístico, Madrid, 1996, p. 133.

40 A. Muñoz Cosme, La conservación del Patrimonio arquitectónico español, Madrid, 1989, p. 119 concepción superficial de la arquitectura donde primaba lo formalista, ornamental y anecdótico sobre lo esencial. Este tipo de actuación vino favorecido por la inmensa permisividad mostrada por el régimen con respecto al tratamiento de los edificios históricos, sufriendo una resemantización radical en aras del querido monumentalismo, patente en muchos ejemplos de Castilla y León ${ }^{41}$.

A la hora de analizar la conservación arquitectónica durante el franquismo, la generalidad de los estudios denuncia la crisis por la que pasó el patrimonio monumental español en aquella época, donde la catalogación arquitectónica sufrió escasa atención oficial y hubo una total ausencia de políticas activas para su protección ${ }^{42}$. Esta situación se debió a varias causas, entre las que podíamos destacar una legislación insuficiente, la politización de la cuestión arquitectónica, la desaparición de los principales defensores de las tesis conservacionistas, el uso libérrimo de las teorías restauradoras, las fatales consecuencias de la especulación urbanística, la falta de agilidad de la administración para actuar en casos concretos, $\mathrm{o}$, entre otras, la evidente escasez de dinero para llevar a cabo las actuaciones más necesarias. Más preocupante es constatar que todavía en los años finales del régimen se mantenían las líneas de actuación dentro del más anticuado tradicionalismo, se desconocían los nuevos métodos e instrumentos de intervención, seguía siendo escaso el aparato teórico y los proyectos se hacían sin estudios serios ni investigaciones previas ${ }^{43}$.

\footnotetext{
${ }^{41}$ J. ARReCheA Miguel, "Arquitectura”, en Historia del Arte de Castilla y León. Arte Contemporáneo, t. VIII, p. 106.

${ }^{42}$ A. MuÑoz CoSME, La conservación..., p. 52.

43 ÍDEM, p. 147.
} 
A continuación pasamos a analizar el traslado de cuatro monumentos a distintos puntos de la ciudad de León, ordenados cronológicamente por el año de su restauración. Eran edificios significativos, tanto por su categoría como por ser representativos de diversas tipologías arquitectónicas. Veremos un monasterio cargado de historia, dos residencias nobiliarias de desigual rango y un establecimiento fabril, construidos entre finales del siglo XVI y mediados del XVIII. Todos eran dignos de ser atendidos para conservarlos en su lugar, y ninguno estaba amenazado por causas excepcionales que aconsejaran su traslado.

Curiosamente estas actuaciones coinciden con una época de gran especulación inmobiliaria en las ciudades españolas, que tuvo su punto culminante en las décadas de los sesenta y setenta, con la demolición de muchos edificios monumentales.

Los ejemplos aquí analizados son los más relevantes del período en León, pero hubo otros intentos y proyectos que no se llegaron a realizar por diversas circunstancias. Da la sensación de que había un interés generalizado por trasladar fachadas monumentales y adornar con ellas edificios nuevos, evitando las formas de la arquitectura moderna y confiriendo a las obras un grado de monumentalismo que estaba más cerca del pretendido estilo nacional. Con ello parece que se satisfacía la idea que tenía el franquismo de la arquitectura, retornando metafóricamente a un pasado triunfal donde el régimen quería tener sus raíces. Así, por ejemplo, se pensó en poner una fachada histórica, producto de un traslado, al santuario de la Virgen del Camino, a la Casa de Cultura de la Diputación, y a varias parroquias de la capital.

Un protagonista destacado en la cuestión que vamos a tratar, fue el obispo de León don Luis Almarcha Hernández, quien durante su permanencia a la cabeza del episcopado leonés (1944-1970) mostró un destacado interés por el patrimonio artístico de su diócesis ${ }^{44}$. Prueba de ello es la creación del Museo Diocesano de Arte Sacro y de la Escuela Superior de Arte Sagrado, o la institución de la Secretaría Técnica de Arte Sacro, además de intervenir en la reparación de decenas de parroquias ${ }^{45}$. Aparte de las actuaciones efectivas tuvo otros proyectos no consumados, como las actuaciones en las parroquias citadas más arriba $^{46}$, pero uno de los llamativos fue la idea de trasladar la iglesia mozárabe de San Miguel de Escalada a León, para colocarla en el solar del desparecido cementerio municipal a las afueras de la capital, rodeándola de un extenso jardín ${ }^{47}$. Finalmente, con buen criterio, se optó por restaurarla in situ.

Para valorar con equidad la actuación del prelado hay que tener en cuenta al mismo tiempo la inoperancia de la Administración en acciones restauradoras, razón por la cual el obispo, como personaje

${ }^{44}$ En 1969 se le concedió la medalla de oro de la Real Academia de Bellas Artes de San Fernando, "en atención a los relevantes méritos contraídos en la defensa y promoción del Tesoro Artístico Nacional".

${ }^{45}$ Sobre la biografía, el pensamiento, y la actividad de este prelado se puede consultar, G. GARCíA GARCÍA, "Datos de un pontificado", en Instituciones Diocesanas, León, 1970; J. M. FERNÁNDEZ CATÓN, "Don Luis Almarcha Hernández, veintiséis años de historia del episcopologio leonés en el siglo XX", Archivos Leoneses, no 57-58, León, 1975, pp. IX-XXIV.

L os escritos del Dr Almarcha se recogen en cuatro volúmenes publicados en 1970 por el Centro de Estudios "San Isidoro" de León: I La cooperación como sistema económico-social, II Ideas sociales, III Escritos doctrinales y pastorales, IV Instituciones diocesanas.

${ }^{46}$ G. García García, "Datos de un pontificado..., p. 338

47 Así lo cuenta J. EgUIAGARAY PALlarÉs, Recuerdos de una barca varada, León, 1971, p. 91. Este autor, que fue alcalde de León (1946-51), dedica un capítulo de su libro al obispo Almarcha, con el elocuente título "Lo que rescató un obispo en León". 
relevante que era en aquella sociedad del nacional catolicismo, ejerció un papel activo en la salvaguardia de edificios antiguos. $\mathrm{Ni}$ el Servicio de Defensa del Patrimonio Artístico Nacional, creado en 1938 y vigente hasta 1974, ni ninguna de sus comisarias dependientes tomaban la iniciativa a pesar de ser órganos ejecutivos. Tampoco lo hizo el Servicio de Restauración de Monumentos, dependiente de la Dirección General de Arquitectura, o la Dirección General de Bellas Artes, que también tenía competencias en arquitectura. Así que el obispo Almarcha se condujo según su peculiar manera de entender la conservación y restauración, poniendo sobre todo voluntad para salvar ciertas obras de la ruina, pero su actuación contaba con el riesgo de dejarlas maltrechas para siempre si se utilizaban criterios erróneos.

La Comisión de Arte Sacro ${ }^{48}$, creada en 1948, estaba más preocupada, como era lógico, por el decoro y la satisfacción de las necesidades litúrgicas de los templos que por sus valores estéticos. No obstante, estableció interesantes recomendaciones en relación con la conservación y restauración. Así, en la reglamentación se ordena que antes de iniciar cualquier intervención se debe consultar con las Comisiones Diocesanas de Arte Sacro y de Monumentos, porque una mala restauración acarrea más daños que la incuria y el tiempo ${ }^{49}$. A la hora de fijar criterios de restauración, defiende teóricamente lo que después no siempre se lleva a la práctica, como veremos. Por ejemplo, aconseja ante todo

\footnotetext{
${ }^{48}$ La intención de esta institución era establecer una normativa estricta para controlar todos los aspectos relacionados con el arte religioso, tanto en arquitectura, escultura y pintura como en las artes suntuarias. Las normas se recogen en L. ALMARCHA, Instituciones diocesanas..., p. 191-209. Las opiniones del obispo sobre el sentido y el significado del arte sacro se recogen en Escritos doctrinales..., pp. 447-485.

${ }^{49}$ L. AlmARCHA, Instituciones diocesanas..., p. 197.
}

consolidar y conservar todo lo que tenga valor, aunque sea de diferentes épocas, sin problemáticos añadidos, sin imitaciones de estilo y sin pátinas falaces ${ }^{50}$.

Antes de empezar con los ejemplos leoneses queremos destacar que percibimos en ellos la idea de la restauración entendida como un proceso creativo, ya que el arquitecto realiza una nueva imagen, quizá arquitectónicamente válida, pero que como conservación resulta falsa. Se recrearon edificios del pasado, presentándoles como podrían haber sido, actuación acorde con la práctica habitual en la España de aquellos momentos, que defendía la conservación dentro del tradicionalismo propio de la escuela restauradora y con una tendencia al monumentalismo ${ }^{51}$. Se utilizaron los edificios históricos como pretexto para materializar una idea subjetiva, con lo que se produjo una transformación, no una restitución de la imagen original. Con lo expuesto no queremos defender posturas conservacionistas a ultranza, sino la autenticidad en las acciones restauradoras desde la sinceridad científica.

\section{I) MONASTERIO DE SAN PEDRO DE ESLONZA}

Este monasterio benedictino ${ }^{52}$, situado en las inmediaciones del pueblo de

\footnotetext{
50 ÍDEM, p. 197-198.

51 A. MuÑoz Cosme, La conservación ..., p. 147.

52 Sobre el monasterio hay una amplia historiografía, entre la que destacamos, para no ser prolijos, la siguiente: J. M. QUADRADO, Recuerdos y bellezas de España. Asturias y León, Madrid, 1855, pp. 378 y ss.; M. GóMEZ MORENO, Catálogo monumental de la provincia de León, León, 1925, pp. 525-527; A. CALVO, San Pedro de Eslonza, Madrid, 1957; M. BRAVO, "Historia del monasterio de Eslonza", Archivos Leoneses, no 1 y 3, pp. 141-161 y 89-112, León 1947-48; C. Rodicio, "Fray Pedro Martínez y la fachada del monasterio de San Pedro de Eslonza", Tierras de León, no 34-35, León, 1979, pp. 49-53; J. RIVERA BLANCO, La arquitectura de la segunda mitad del siglo XVI en León,
} 
Santa Olaja de Eslonza, era uno de los más antiguos del reino de León según dicen las crónicas, y llegó a ser uno de los primeros de la diócesis de León en cuanto a riqueza y poder. Fundado por el rey García I en el año 912 y destruido durante la invasión de Almanzor, fue levantado de nuevo hacia 1099 gracias a la infanta doña Urraca, hermana de Alfonso VI. Entre los siglos XVI y XVIII se llevaron a cabo una serie de obras para adecuarlo a las nuevas necesidades y gustos, de manera que subsistieron pocos elementos de la fábrica románica. Con el deseo de hacer un monasterio de la mayor categoría artística, en cada época se contrataron a los arquitectos de más reconocido prestigio, como Juan de Badajoz "el Mozo", Juan López de Rojas, Juan de Ribero Rada, y por último a fray Pedro Martínez de Cardeña.

Su historia se trunca en 1835 con la desamortización de Mendizábal, quedando a partir de ese momento abandonado y expuesto a las veleidades de sucesivos propietarios y al saqueo de sus materiales, como prueba la existencia de elementos arquitectónicos de procedencia incontestable en muchos edificios de la zona. A pesar de que el edificio fue declarado Monumento Histórico en 193153, su estado de abandono y la falta de aten-ciones hicieron que su deterioro llegara a ser preocupante. Hacia 1940 el arquitecto Juan Torbado Franco, alarmado por el estado del monumento, estudió las ruinas con la intención de darlas una utilidad que salvara

León, León, 1982 pp. 163-169; M. D. CAMPOS, "El monasterio de San Pedro de Eslonza, modelo de las reformas arquitectónicas de la Orden de San Benito en el siglo XVI", Estudios Humanísticos, no 13, León, 1991, pp. 271-285; A. Rodríguez G. DE CEBALlOS, Arquitectura barroca en Castilla y León, Salamanca, 1996, p. 88; E. MORAIS VALLejO, Aportación al barroco en la provincia de León. Arquitectura religiosa, León, 2000, pp. 283-287.

53 J. Rivera Blanco, Catálogo Monumental de Castilla y León, Salamanca, 1995, pp. 392-393. en lo posible los restos del cenobio ${ }^{54}$. En un primer momento propuso a la Diputación Provincial su reconstrucción para destinarlo a manicomio, aprovechando las estructuras todavía utilizables, pero su idea no fue aceptada ${ }^{55}$.

Después de pasar por varios dueños, en 1946 el obispado de León compró los restos del monasterio de Eslonza, por 100.000 pesetas, volviendo así a ser propiedad eclesiástica ${ }^{56}$. La idea era salvar al edificio de su ruina, pero lo difícil era reconstruirlo y conferirle una utilidad viable en su ubicación. Al año siguiente el obispo Almarcha encontró la solución, drástica aunque controvertida: el traslado de algunas partes para aplicarlas en la construcción de una nueva iglesia parroquial en la ciudad de León.

El populoso barrio de Renueva disponía de un templo antiguo bajo la advocación de San Juan, situado en la plaza del mismo nombre. Su fábrica era pobre y de aspecto rural, y al parecer sin valor para el obispado, que no dudó en derruirlo sin dejar huella de su existencia. Se daba la circunstancia de que su ubicación molestaba para el tránsito de la estación de ferrocarril de FEVE, por lo que el ayuntamiento vio la oportunidad de aprovechar su demolición para reorganizar el lugar, ensanchando la plaza y cambiando la clasificación urbanística de la zona afectada, con el significado especulativo que de la operación se puede deducir. De esta manera la iglesia moderna se construyó en un solar distinto, situada a cierta distancia de la primitiva y más alejada del centro.

54 A. CALVO, ob. cit., pp. 205-206, hace una descripción de las ruinas del edificio conforme a lo visto en una visita realizada en 1930.

55 J. TORBADO, "Traslado del Monasterio de Eslonza", Archivos Leoneses, no 1, León, 1947, p. 185.

${ }^{56}$ A. CALvo, ob. cit., pp. 203-204. 
El encargado de proyectar y dirigir la construcción del nuevo edificio, así como de realizar el traslado desde Eslonza de todos los elementos reutilizables del monasterio, fue el citado arquitecto Juan Torbado Franco ${ }^{57}$. En 1947 se empezaron a desmontar las partes del edificio monacal que se consideraban aprovechables, tanto para el templo de Renueva como para otros posibles servicios. Lo que no se pudo aprovechar se dejó abandonado a su suerte, olvidado ya para siempre y degradándose de manera irremediable ${ }^{58}$.

En el proyecto de la obra hay una memoria descriptiva, tan escueta y falta de datos como era habitual en la época ${ }^{59}$. Carece de un verdadero estudio históricoartístico del edificio, sin aportar tampoco las motivaciones ni los objetivos del traslado. La única explicación que se da como justificación es el gran cariño que el prelado siente por el Arte y la Arqueología, así

\footnotetext{
57 Juan Torbado Franco, hijo del arquitecto y restaurador de la catedral de León, Juan Crisóstomo Torbado Flórez, estuvo activo en la capital entre las décadas de los 30 y 60, ocupando varios cargos oficiales como Delegado Provincial de Bellas Artes, arquitecto del obispado de León, arquitecto conservador de monumentos de la $1^{\text {a }}$ zona del Patrimonio Artístico Nacional. Además de hacer restauraciones de edificios antiguos, también realizó interesantes edificios siguiendo tendencias cercanas a la arquitectura racionalista. Sobre su obra véase $M$. A. BALDELlOU, Arquitectura española del siglo XX, en Summa Artis, t. XL, Madrid, 1995, pp. 257-261; AA. VV., León. Casco Antiguo y Ensanche. Guía de arquitectura, León 2000, pp. 72, 124, 128, 136, 176; A. PIZZA, Guía de la arquitectura del siglo XX. España, Madrid, 1997, p. 92; J. C. PONGA MAYO, El ensanche de la ciudad de León 1900-1950, León, 1997, pp. 146-150.

58 J. M. VillanUeVA LÁZARO, La ciudad de León, del gótico a nuestros días, León, 1980, p. 142, afirma que las arcadas de las crujías de oriente y poniente del claustro se encuentran desmontadas y guardadas.

${ }^{59} \mathrm{El}$ proyecto de la obra, firmado en julio de 1946 y cuyo presupuesto ascendía a un total de 4.790.829,28 pesetas, se encuentra en el Archivo del Colegio Oficial de Arquitectos de León (a partir de ahora A. COAL), Expediente $\mathrm{n}^{\circ} \mathrm{0} 42.214$.
}

como por la historia y la tradición de nuestra Patria, ha dado origen a que tuviese la tan feliz y acertada idea de utilizar para la erección del nuevo templo todos los elementos aprovechables del célebre Monasterio de Eslonza, hoy en ruinas, evitando así que lleguen a desaparecer los restos que hasta nosotros a través del tiempo $y$ de los hombres han llegado. En cuanto a decoración y estilo - dice el autor- están determinados por el monasterio cuyos restos utilizamos $y$ al que hemos tratado de adaptarnos $^{60}$. Con estas palabras se justifica la realización de una obra de corte historicista.

En el artículo que publicó el arquitecto con motivo de la reconstrucción, tampoco existen mayores explicaciones. Aquí justifica el traslado porque así se podría contemplar los restos del edificio más a nuestro gusto por estar en la Capital ${ }^{61}$, como si el disfrute estético estuviera destinado a unos pocos elegidos, a los que se debían acercar las obras.

El aspecto funcional de la obra vino determinado por las nuevas necesidades, con independencia del edificio primigenio que se quería preservar. De ahí que la distribución, formas y dimensiones no se corresponden con las del antiguo templo monacal, sino con las exigencias de la nueva parroquia. Para hacer la iglesia de Renueva se utilizaron varios componentes del monasterio de Eslonza, pero se trastocaron sus primitivas ubicaciones, se acoplaron a los lugares que le convenía al arquitecto, sin tener en cuenta usos, significados, ni perspectivas. La idea del traslado no consistía en trasplantar la iglesia monacal a un barrio de León, sino hacer un templo nuevo y engalanarlo con elementos de un edificio histórico, como si los componentes de un monumento fueran

\footnotetext{
60 ÍDEM, p. 1-3.

${ }^{61}$ J. TORBADO, ob. cit., p. 185.
} 
ornamentos muebles que se pueden quitar y poner con las enmiendas necesarias.

Las portadas renacentistas, atribuidas a Juan de Badajoz "el Mozo" y sus seguidores, se reubicaron en lugares diversos. En el brazo norte del crucero se colocó la entrada principal del monasterio. La que daba al claustro hoy es la puerta de acceso a la iglesia, ubicada en un receptáculo que impide apreciarla en toda su dimensión ${ }^{62}$. La portada de la sala capitular ahora está en el exterior del muro norte. El orden jónico de la portada del refectorio adorna un angosto callejón delante del muro sur. Sillares, molduras, nervios, claves, ménsulas, y demás elementos arquitectónicos se colocaron en distintas partes del edificio, como joyas antiguas ataviando al nuevo edificio.

Pero el elemento más destacado, protagonista máximo del traslado, es la fachada principal de la iglesia, realizada en el barroco por fray Pedro Martínez de Cardeña. Se colocó en la misma situación y con la misma función primitiva, aunque con alteraciones en su enmarque que cambiaron su fisonomía y proporción iniciales. El templo monástico era de una sola nave y a ella se acomodaba la fachada; al decidir hacer la nueva parroquia con tres naves, Torbado añadió una torre campanario a cada lado de la fachada para acoplarse a la nueva anchura proyectada ${ }^{63}$. Las torres, esbeltas y desmesuradamente altas, desvirtúan el valor de la portada con la que armonizan mal en su historicismo. Para salvar el desnivel hasta la calle, dispuso delante de la fachada una gran escalinata, de sentido grandilocuente, que tampoco

62 En la clave del arco una cartela, ahora movida de su sitio, cita al abad Diego Lucio y al arquitecto Juan de Badajoz como promotor y ejecutor respectivamente de la gran reforma del monasterio en el siglo XVI.
}

${ }^{63}$ J. TORBADO, ob. cit., p. 185. estaba en la obra primitiva. Estas modificaciones, unidas al cambio de ubicación y al distinto ambiente en el que se acopló, producen una alteración del diseño original, de forma tal que transforman sustancialmente los códigos barrocos de la obra.

El interior es toda una recreación, con unos cuantos restos del monasterio ubicados estratégicamente para recordar la primitiva iglesia monacal. Torbado, desde presupuestos historicistas, hizo una iglesia "neorrenacentista" de amplias dimensiones.

\section{II) PORTADA DE LA REAL FÁBRICA DE TEJIDOS E HILADOS DE LEÓN.}

José Carvajal y Lancáster, Secretario de Estado de Fernando VI, decidió establecer una fábrica de tejidos en la ciudad de León. Era una operación más para llevar a cabo su política económica mercantilista, utilizada para reactivar la economía nacional creando una serie de fábricas con capital estatal que perseguían fomentar la actividad industrial. A finales de 1751 se publicó una Real Orden por la que se asignaban mil doblones mensuales para el funcionamiento de la fábrica, ubicada en las antiguas Casas Reales ${ }^{64}$. Ese mismo año la empresa fabril estaba ya en pleno funcionamiento, para lo cual se contrataron técnicos flamencos $u$ holandeses de gran tradición en el oficio ${ }^{65}$. En 1754, en vista del buen comportamiento de la fábrica, se decidió construir un nuevo

\footnotetext{
${ }^{64}$ La historia de la fábrica se trata en J. L. MARTíN GALINDO, La ciudad de León en el siglo XVIII, León, 1959, pp. 52-55; también en AA. VV., Historia de León. Edad Moderna, León, 1999, pp. 388-392. No hay ningún estudio arquitectónico documentado de la Puerta de la Reina ni del edificio fabril, sólo escuetas referencias y descripciones formales, por ejemplo J. M. VILLANUEVA LÁZARO, op. cit, p. 161.

65 Los nombres de los técnicos los proporciona J. L. MARTÍN GALINDO, ob. cit, p. 54.
} 
inmueble para ampliar las dependencias e introducir mayor maquinaria y más moderna, eligiéndose para ello el solar contiguo al Campo de san Francisco ${ }^{66}$. La nueva factoría estuvo funcionando poco tiempo, hasta 1769, que fue cerrada y aprovechada por el ayuntamiento para establecer en su lugar el Hospicio que siempre había anhelado ${ }^{67}$.

La fábrica tenía una portada monumental, conocida popularmente como Puerta de la Reina, que pasa por ser una de las más interesantes del escaso repertorio barroco civil de León. Su fuerte carácter emblemático, expresado mediante relieves, esculturas y cartelas con inscripciones, vincula a la monarquía con la defensa y progreso de las artes, la industria y el comercio ${ }^{68}$. En sendos medallones se representan los bustos de Fernando VI y de la reina María Bárbara de Braganza, entre los cuales se representa un león con dos globos terráqueos, en alusión a las posesiones de ultramar. El segundo cuerpo, conformado por una gran peineta en la que se destaca el escudo de la monarquía con el collar del Toisón de oro y timbrado con la corona real, se remata con una efigie identificada con la Constancia y el Trabajo, mientras que las otras dos que la acompañan representan al Comercio y a las

\footnotetext{
66 Según el plano de Risco, realizado en el siglo XVIII, estaría entre la puerta del Malbar y la puerta de san Francisco, en el lado meridional de la cerca medieval de la ciudad.

${ }^{67} \mathrm{Sin}$ duda en el cierre influyeron las nuevas ideas políticas ilustradas del reinado de Carlos III, más proclive a la fisiocracia y a la defensa de la agricultura que a las teorías mercantilistas.

${ }^{68}$ En la cartela situada en la base del edículo, se puede leer, no sin dificultad por su deterioro, la siguiente leyenda: FERDINAND VI HISPANIARUM AC INDIARUM REGI CATOLICO PIO INCLITO FAELICI QUOD OMMES, OMNIUM ANTE SE MAXIMORUM REGUM GLORIAS SUPER GRESUS LEGIONENSUM. ARTIBUS AC COMERCIIS RESTITUIS ET AUCILIS OMNI INDULGENTIA ET LIBERALITATAE AIUS
}

Bellas Artes. Todo hace alusión a la condición del edificio primigenio, donde se tenía la intención de conjugar la actividad económica con la artística.

La obra se inscribe en la estética final del barroco, con gusto por el movimiento en planta, los adornos de formas curvilíneas, cercanos a la rocalla, y una tendencia a lo recargado y ornamental. Sin embargo, todo este elaborado discurso iconográfico y morfológico queda desvirtuado en su nueva ubicación, ya que la portada fue desmontada a mediados del siglo XX y trasladada para servir de adorno al nuevo edificio de la Audiencia Provincial de León, donde hoy se encuentra ubicada.

Para levantar la sede de la judicatura también se derribó la mansión de los Quiñones Acebedo ${ }^{69}$, sin atender a los blasones que ostentaba en su fachada y a la historia que atesoraban sus piedras. El inmueble, que había sido la Casa de la Beneficencia, pertenecía desde 1895 al Ayuntamiento, quien lo cedió al Ministerio de Justicia para levantar en su lugar la citada Audiencia ${ }^{70}$.

Javier Barroso fue el encargado de hacer el proyecto de la nueva obra ${ }^{71}$, así

${ }^{69}$ La historiografía no es unánime al respecto, pues para algunos en el solar estaba el palacio de lo Cea, cfr. J. M. Villanueva LÁZARO, ob. cit, p. 123, mientras que P. CiMADEVILla SÁNCHEZ, ob. cit., p. 462, cree que estaba la mansión de los Quiñones Acebedo. Sobre la historia del edificio de los Cea véase, $\mathrm{M}$. BRAVO GUARIDA, Rincones leoneses, León, 1979 (reedición), pp. 21-25.

70 Todo el proceso, con los distintos trámites que tuvieron lugar, ha sido tratado en T. BURÓN CASTRO, "Palacio de la Audiencia Provincial", Locus Appellationis, no 36, León, 2000, pp. 41-43.

${ }^{71}$ Por aquella época se construyeron en provincias diversos edificios para la Administración Central, los cuales se encargaban a arquitectos que no procedían del ámbito local, sino que eran designados directamente por el organismo competente desde Madrid. Por esa razón el proyecto de la obra, así como toda la documentación referente al traslado, no se 
como de ponerlo posteriormente en práctica. El autor era arquitecto de la Real Academia de Bellas Artes de San Fernando ${ }^{72}$, ejerciendo entonces su profesión también en el Ministerio de Justicia ${ }^{73}$. La construcción se decidió en 1944, los trabajos comenzaron el año siguiente y culminaron en 1950, autorizándose el 14 de abril el traslado desde la antigua sede de la plaza del Rastro al nuevo palacio judicial ${ }^{74}$. Para dar mayor prestancia a su fachada, la Diputación Provincial tuvo la idea de ceder gratuitamente la portada de la Real Fábrica de Tejidos e Hilados ${ }^{75}$, que por entonces era la Residencia Provincial de Huérfanos, institución que seguía en funcionamiento y a la cual se la privaba de su elemento más suntuoso, sin ninguna razón convincente que lo justificara ${ }^{76}$.

Desde un principio se pensó en utilizar la portada monumental, como se puede comprobar en el dibujo del proyecto

halla en el A. COAL. El proyecto se presentó en Madrid y ahora se guarda en el Archivo General de Administración del Ministerio de Justicia, cajas 87/61 y 87/76. Agradecemos a Taurino Burón Castro la amabilidad que ha tenido al proporcionarnos la fuente.

72 Javier Barroso fue uno de los arquitectos encargados de hacer la reconstrucción de la Ciudad Universitaria de Madrid, prácticamente destruida al ser frente de batalla durante mucho tiempo en la Guerra Civil. Trabajó a partir de 1941 en la reedificación de los colegios mayores Nebrija y Cisneros, y en la construcción de los denominados Menéndez Pelayo y Covarrubias, según se recoge en M. A. BALDELLOU, ob. cit., p. 199. Junto con Luis M. de Gana Hoyos inició la construcción del estadio de futbol del Manzanares, A. URRUTIA, Arquitectura española. Siglo XX, Madrid, 1997, p. 393.

${ }^{73}$ T. BURÓn CASTRO,"Palacio de la Audiencia..., p. 46.

${ }^{74}$ ÍDEM, p. 43-45.

${ }^{75}$ La cesión de la "Puerta de la Reina" al Ministerio de Justicia se hizo el 11 de enero de 1945.

${ }^{76}$ Se da la circunstancia de que en noviembre de 1946 la Diputación insta al Ministerio de Justicia a desmantelar la portada para proceder al cerramiento del hueco que quedara después del traslado. de Barroso, no contemplándose una solución alternativa. En esta ocasión no se trataba de salvar un edificio porque estuviera en ruina o abandonado, ya que precisamente era propiedad de la Diputación, organismo especialmente obliga-do a mantener y cuidar el patrimonio monumental de la provincia. En un acto -que resulta del todo incomprensible- las autoridades provinciales cedieron primero la propiedad de una obra de gran relevancia histórica y artística, y luego permitieron su traslado para adornar un edificio que no lo precisaba en absoluto. Por curiosidad, constatamos que en el solar de la real fábrica se levantó, poco tiempo después del expolio, un edificio destinado a albergar algunas de las más importantes dependencias culturales de la Diputación.

La fachada del inmueble fabril se desmontó del conjunto monumental como si fuera un postizo, realizándose sin dilación el traslado al nuevo emplazamiento. El arquitecto, en la declaración de intenciones recogidas en la memoria del proyecto, indicaba que la portada sería respetada en su forma original, repasándola y reponiendo las partes que lo necesiten, con piedra, a poder ser vieja, con objeto de conservar todo lo posible su carácter antiguo ${ }^{77}$. No obstante, sí se hicieron modificaciones ya que a ambos lados de la entrada había unos muros retraídos, y hoy en su lugar se han abierto unas tristes ventanas que distorsionan la composición del conjunto.

El edificio diseñado por Barroso quiere hacer un guiño a la arquitectura histórica y así se dispone entre dos volúmenes que hacen de torreones cuadrangulares, recordando el esquema palaciego renacentista de gran tradición en la arqui-

77 Recogido del proyecto en T. BURÓN CASTRO, $o b$. cit., p. 45. 
tectura española. En el centro se colocó la portada prestada, embutida en un entrante de la fachada y constriñida entre sus muros, de manera que sus peculiares valores quedaron modificados, cuando no anulados. Su realidad estética fue adulterada y la relación con el edificio adosado no se parece en nada a los presupuestos con los que fue diseñada primigeniamente. Distinto edificio, otra función y diferentes valores estilísticos de dos maneras de interpretar la arquitectura que no conjugan ni se articulan. Sirva como muestra, que prueba lo que estamos diciendo, el telón de fondo que se dio a la peineta, con unos vanos semiocultos, casi clandestinos, que degradan la labor exornativa del edículo.

Con esta manipulación arquitectónica queda patente el olvido de los valores intrínsecos del edificio, utilizando sus elementos como si fueran intercambiables. Hay una merma de la condición decorativa de la arquitectura, pensando que sus motivos se pueden disponer sin la adecuada articulación con los demás elementos del conjunto. Además, se desmanteló un monumento histórico-artístico para vestir un edificio moderno sin relación de ningún tipo ni con el primitivo ni con su ambiente.

\section{III) CASA BLASONADA DE LOS QUIRÓS.}

La mansión nobiliaria de la familia leonesa de los Quirós estaba originariamente ubicada en la calle Daoíz y Velarde de León (ahora Pablo Flórez). Desconocemos la apariencia completa del edificio porque los escasos documentos gráficos que se conservan son fragmentarios y de poca calidad. Por otro lado no existe ningún tipo de historiografía que lo trate, ni tampoco se han encontrado en los archivos datos documentales sobre él. La única referencia concreta es la descripción del escudo que campeaba en sus muros, donde se reúnen las armas de los linajes de
Quirós, Miranda, Bravo y Acuña, además de exhibir una cruz de la orden de Santiago de fondo ${ }^{78}$.

Resulta arriesgado, por tanto, fijar una fecha de construcción para la fachada. Por otro lado, las alteraciones sufridas tras su traslado, así como la falta del edificio original al que estaba unido, tampoco permiten hacer un análisis estilístico solvente. Podemos aventurar que el parejo y los restos arquitectónicos conservados en vanos, entablamentos, cornisas, frontones y molduras fueron concebidos dentro de unos parámetros canónicos, lo que indica que su construcción debió hacerse en la etapa clasicista de la arquitectura españo$\mathrm{la}^{79}$, entre finales del siglo XVI y las primeras décadas del siguiente.

Hoy sólo subsisten del edificio original algunos elementos de su fachada principal, formando parte de un edificio de nueva planta dentro del complejo de san Isidoro, producto de un traslado. Hacia 1960 la casa presentaba un deterioro considerable, hasta el punto que se pensaba declararla en ruina para derribarla. El arquitecto restaurador Luis Menéndez Pidal, que entonces estaba trabajando en León, se propuso salvar de la piqueta al menos la fachada. Lo primordial era encontrar una nueva función y un edificio al que adosarla, encontrándose en la reforma que por aquellos años se había decidido hacer en la colegiata de San Isidoro, que llevaba asociada una redistri-

${ }^{78}$ F. CADENAS y VICENT, Armería en piedra de la ciudad de León, León, 1948, p. 45. Otros escudos de los Quirós se encontraban en las paredes del palacio de los marqueses de Villasinda y en una casa de la antigua calle del Paso, ÍDEM, pp. 44 y 46. También en CIMADEVILLA SÁNCHEZ, P., Repertorio heráldico leonés, v. III, pp. 140-143

${ }^{79}$ La tipología de las casas nobiliarias de esta época en Castilla y León fue estudiada por A. BUSTAMANTE GARCÍA, La arquitectura clasicista del foco vallisoletano (1561-1640), Valladolid, 1983, p. 536 
bución y aumento de sus dependencias para satisfacer las necesidades del complejo conventual. En él coexistían los específicos recintos de un convento $y$ otros que cumplían funciones añadidas con el paso del tiempo, como la residencia de canónigos, la residencia de religiosas, la casa de ejercicios espirituales y el convictorio sacerdotal, junto con el museo y la zona turística. Entre las ampliaciones que se pretendían hacer se encontraba la construcción de una sede para la Escuela Superior de Arte Sacro ${ }^{80}$. El lugar elegido para erigirla fue el atrio trasero del convento, en el solar que ocupaban las ruinas de la antigua abadía isidoriana, decidiéndose utilizar para confeccionar su fachada los materiales aprovechables de la mansión de los Quirós.

El encargado de elaborar el proyecto de la obra fue el arquitecto Juan Torbado Franco, quien se ocuparía asimismo del traslado de los restos del edificio nobiliario y de su reconstrucción en la nueva ubicación. La memoria redactada con motivo del proyecto, y firmada en marzo de 1962, es muy simple, sin ningún tipo de indicación de carácter histórico ni documental sobre el edificio que se pensaba reconstruir, tan sólo unas tópicas alusiones a la historia de la colegiata ${ }^{81}$. En ella se indica que se dispone de una magnífica $y$ monumental fachada de estilo neoclásico, labrada en sillares de piedra de Boñar, desmontada del antiguo palacio de los Quirós de la calle de Daoíz y Velarde de León hace un año porque amenazaba ruina inminente $y$ donada a la Colegiata por su propietario. Los demás apartados del documento quedan reducidos a la memoria de calidades de materiales, los dibujos de las plantas y el alzado

${ }^{80}$ Los objetivos, normas y organización de la Escuela quedan recogidos en L. ALMARCHA, Instituciones Diocesanas... pp. 59-61.

${ }^{81}$ A.COAL, Expediente 42.542. del edificio, y la determinación del presupuesto total de la obra, que ascendía a 4.140.211' 45 pesetas. Nada se esgrime para defender el traslado y la reconstrucción posterior de la fachada, ni los presupuestos especulativos de la reconstrucción. Carecemos, por tanto, de la justificación teórica en la que se fundamenta el tipo de conservación elegida por el arquitecto restaurador ${ }^{82}$.

Aprovechando la ocasión se quiso regularizar el atrio, para lo cual se tiró el viejo edificio de la abadía isidoriana, del que no queda ningún vestigio en la actualidad, dejando espacio al nuevo inmueble. Ahora se dispuso la nueva fachada paralela al lienzo trasero del convento de san Isidoro -corrigiendo la desviación oblicua que tenía la mansión abacial- formando ángulo recto con el colindante claustro barroco y dando frente a la portada prioral que realizara el maestro Juan del Ribero Rada. La idea era componer un patio de carácter monumental, añadiendo a los edificios existentes los restos de la casa nobiliaria.

La actual fachada, realizada con buenos sillares de piedra de Boñar aprovechados del edificio primigenio, se organiza en tres alturas. La inferior está elevada sobre un pequeño zócalo, hecho con piedra no perteneciente a la fábrica original, de manera que se accede a la portada por medio de una pequeña escalinata, tampoco constatada en el edificio antiguo. A la fachada se le añadió un edificio de escaso fondo, que en su apariencia quiere simular una antigüedad que no tiene.

${ }^{82}$ En la década de los 60 todavía en España los proyectos son muy someros, y con frecuencia no tienen ni la más elemental referencia ni dataciones históricas, con lo que las restauraciones se convierten en una visión subjetiva del arquitecto, como expone A. MuÑoz Cosme, La conservación..., p. 148. 
Entre el proyecto original y la realización final hay varias modificaciones, como la disposición de las ventanas del piso superior, que al final fueron siete y no ocho como inicialmente se pensaba, lo que motivó la colocación del escudo de armas en una situación desviada con respecto al eje axial de la portada, que hubiera sido lo más correcto. Por cierto, el escudo de armas previsto en los dibujos del restaurador correspondía al obispo Almarcha, aunque finalmente se colocó el primitivo nobiliario.

Al levantar el nuevo edificio se hizo la recreación de una fachada palaciega a partir de unos restos antiguos, pero sin la intención de reproducir miméticamente el monumento histórico original, sino haciendo una obra personal con sentido historicista. La fachada nunca fue así, pero se presenta como podría haber sido. Por lo tanto, más que restauración tendríamos que hablar de un ejercicio creativo que ha llevado las teorías de Viollet-le-Duc hasta los extremos ${ }^{83}$. Pero aquí no es posible aducir la coartada de la forma prístina, porque el resultado no tiene la base de la casa nobiliaria antigua, sólo hay una composición de carácter estilista utilizando fragmentos históricos. Se imitaron las molduras antiguas para hacer nuevos vanos y se distribuyeron en una composición inédita; todo se dispuso para que el espectador creyese estar ante una arquitectura verdaderamente histórica, cuando en realidad ha perpetrado un falso histórico ${ }^{84}$ en el que se ha perdido uno de los objetivos de la conservación, el valor documental. En esta ocasión no se dejó ninguna evidencia para diferenciar lo auténtico de lo nuevo, lo que es original y

83 E. VIOLLET-Le-Duc, Dictionnaire raisonnée..., defiende que restaurar un edificio no significa conservarlo, repararlo o rehacerlo, sino obtener su forma prístina, incluso aunque nunca hubiera sido así.

${ }^{84}$ Siguiendo la terminología de A. GonZÁLEZ, "Falso histórico o falso arquitectónico... lo que es mera invención del restaurador. El abuso de este tipo de restauraciones de carácter creativo motivó la contundencia de la Carta de Venecia de 1964 exigiendo autenticidad y rigor en las intervenciones de edificios históricos ${ }^{85}$.

\section{IV) PALACIO DE LOS MARQUESES DE PRADO}

Los Prado, una familia nobiliaria pretendidamente vinculada al linaje de los reyes de León, tenía su palacio solariego en Renedo de Valdetuéjar, un pequeño y alejado pueblo de la montaña occidental leonesa, donde ejercieron su jurisdicción y ostentaron su señorío ${ }^{86}$. El edificio primigenio, acerca del cual desconocemos casi todo, fue reformado hacia el primer tercio del siglo XVII, principalmente para dotarle de una fachada monumental y hacer una capilla funeraria donde albergar los enterramientos familiares. Intentaron, mediante una arquitectura de calidad, que la obra fuera digna de la alcurnia del apellido $^{87}$.

Probablemente fuera Francisco de Prado, gobernador en Aranjuez y después en Cuzco, quien iniciara la remodelación y ampliación del palacio, continuando los trabajos su hermano Antonio, canónigo de la catedral de Murcia e inquisidor en To-

\footnotetext{
85 ÍDEM, p. 16.

${ }^{86}$ La historiografía sobre la familia Prado y su palacio es muy escasa. Los principales datos conocidos se pueden consultar en J. M. PRADO, Los valles del Tuéjar, León, 1979; M. GóMEZ MORENO, Catálogo monumental de la Provincia de León, León 1925, pp. 556559; J. M. VILlanUeVA LÁZARO, ob. cit, p. 134-135; AA.VV., León. Guía de arquitectura, León, 2000, pp. 7273.

${ }^{87}$ J. M. PRADO, en la obra citada, asegura que los arquitectos que dejaron al palacio en su forma definitiva fueron Baltasar Gutiérrez y Juan del Ribero entre 1588 y 1627. No aporta documentación alguna que avale tal afirmación, que a nosotros nos parece poco probable.
} 
ledo $^{88}$. Entre ambos consiguieron hacer uno de los palacios más sobresalientes de toda la provincia leonesa. Buenos muros de trabajada sillería, vanos moldurados, frontones, cornisas, ménsulas, entablamentos y una gran portada, conformaban una interesante muestra de la arquitectura clasicista de principios del siglo XVII. El palacio se organizaba en dos fachadas que formaban ángulo recto, teniéndose previsto ampliar con una tercera, a juzgar por los arranques de arcos que se veían hacia oriente. La orientada al norte era la principal, con una portada monumental donde campeaba un gran escudo con las armas de los Prado $^{89}$. A lo largo de los muros se repetía el mismo escudo, de manera en exceso reiterativa ${ }^{90}$, y aparecían inscripciones con sentencias de sentido barroco, algunas para elogiar el linaje de los Prado, otras con interés aleccionador y carácter conceptista ${ }^{91}$.

${ }^{88}$ Una inscripción en la capilla hacía historia del linaje y fijaba 1625 como fecha de construcción. M. GÓMEZ MORENO, ob. cit., p. 557, la leyó así: A DiOs TODOPODEROSO Y XPO NRO SOR Y A S. JUAN SU GRAN PRIVADO, D. ANTONIO DE PRADO, HIJO DE D. HERNANDO, NIETO DE D. FRANCISCO, CABEZAS DESTE APELLIDO Y SEÑORES DESTA CASSA Y ESTADO, QUE FUNDÓ EL SERENISIMO YNFANTE D. NUÑO DE PRADO, PRIMERO DESTE APELLIDO, HIJO DEL SEÑOR REY D. BERMUDO DE LEÓN EN LOS PRINCIPIOS DE LA RESTAURAÇION DE HESPAÑA, POR SER FRONTERA DE LOS MOROS, DESHECHOS EN PARTE CON EL TIEMPO SUS MUROS, TORRES Y FOSOS, PORQUE DE TAN GRAN PRÍNCIPE DURASE LA MEMORIA, LA REEDIFICÓ Y PUSO EN EL PRESENTE ESTADO, AÑO 1625, DE SU EDAD 39.

${ }^{89}$ M. GÓMEZ MORENO, op. cit, p 557-558.

${ }^{90}$ Los escudos los estudia CIMADEVILLA SÁNCHEZ, P., op. cit., pp. 470-474.

${ }^{91}$ Se conservan, aunque ahora su significado choca con la función del edificio: PRATORUM REGIAE FAMILIAE ECCE SEDES PRIMA. - EN DOMUS ANTIQUA MULTOS DOMINATA PER ANOS. - A DIGNITATE DOMUS ET DOMO DIGNITAS. -IIN MULTITUDINE POPULI HONOR PRINCIPIS. - SUUM CUIQUE DECUS POSTERITAS REPENDIT. - GLORIA NON MORITUR.
Al inicio del siglo $\mathrm{XX}$, aparte de las fachadas descritas, poco quedaba de la construcción primitiva, destacando la cerca de mampostería, una portada del siglo XVI, una vasta nave y una galería hacia poniente, que fue la vivienda señorial. La decadencia del edificio se hizo ya irreversible a partir de 1905, cuando el palacio fue vendido a un industrial leonés y empezó su expolio impenitente, mientras iba pasando de unos propietarios a otros sin que ninguno hiciera nada por su conservación. En el año 1954 fue adquirido por el millonario y mecenas leonés Pablo Díez, quien tenía la intención de utilizar la fachada palaciega para la construcción del nuevo santuario para la Virgen del Camino, que él estaba dispuesto a financiar. La idea se la había proporcionado el obispo Almarcha, quien quería hacer un gran complejo religioso alrededor de la sede de la patrona leonesa ${ }^{92}$. No obstante, el arquitecto que había proyectado el templo mariano, fray Coello de Portugal, no aprobó la unión de su diseño vanguardista con la adición de la fachada barroca, y la idea fue desechada ${ }^{93}$.

Más tarde los restos del palacio pasaron a ser propiedad de la Diputación de León. Entonces se pensó en utilizarlos para ennoblecer la fachada de la nueva Casa de Cultura, con proyecto de Felipe Moreno. Pero también en esta ocasión se rechazó la utilización de las piedras nobiliarias y se llevó a cabo un proyecto totalmente moderno ${ }^{94}$.

Por aquellas fechas el obispo de León y el cabildo de la catedral tenían decidido fundar un hospital destinado a los sacerdotes de la diócesis y otros fines benéficos. Para financiar la fundación, el obispado

\footnotetext{
-

92 L. AlmARCHA, Escritos doctrinales y pastorales..., pp. 221-223

93 J. EGUIAGARAY PALLARES, ob. cit., p. 95.

94 IBÍDEM.
} 
aprovechó el interés del Instituto Nacional de Industria (INI) por el convento de San Marcos para hacer un parador de turismo de gran lujo, y cedió sus derechos al Estado en 1963 por doce millones de pesetas, para la construcción del anhelado hospital. Así nació la denominada Obra Hospitalaria de Nuestra Señora de Regla ${ }^{95}$. El obispo Almarcha negoció al mismo tiempo con la Diputación Provincial la cesión de los restos del palacio para hacer con ellos la fachada principal del centro sanitario. Con la fachada secundaria y los restos de la capilla palaciega se pensaba hacer la parroquia de Puente Castro, pero finalmente estos deseos no se cumplieron ${ }^{96}$. Diversos elementos del palacio como escudos, molduras y sobre todo sillares, se pueden ver en casas de los pueblos de la zona, como muestra del total expolio que se hizo del palacio hasta sus cimientos, de manera que hoy no queda nada en su lugar del impresionante edificio de los marqueses.

Para la erección del nuevo inmueble y la disposición de una plaza aledaña, se utilizó un solar contiguo al claustro de la catedral y a las murallas de la ciudad, ocupado por varias casas que fueron demolidas. Con el fin de facilitar la operación urbanística se arguyó que el derribo lograría aislar la catedral, permitiendo así su total circunvalación ${ }^{97}$, idea defendida con bastante frecuencia a lo largo del siglo XX.

El proyecto de la obra hospitalaria fue realizado por Juan Torbado Franco en $1964^{98}$. En la memoria original no hay ninguna referencia a la utilización de las piedras históricas, así como tampoco en los

${ }^{95}$ Estas vicisitudes las relata el obispo en el decreto de creación de la Obra Hospitalaria, véase, L. ALMARCHA, Instituciones Diocesanas..., pp. 83-87.

${ }^{96}$ J. M. VillanUEVA LÁZARO, ob. cit, p. 135.

${ }^{97}$ L. AlmarCHA, Instituciones diocesanas..., p. 84.

${ }^{98}{ }^{96} \mathrm{~A}$. COAL, Expediente no 02.554 . diseños del alzado se preveía la adaptación de la portada nobiliaria. Torbado había proyectado en un primer momento una fachada muy sencilla, de marcado sentido racionalista, con el único adorno de una portada de cuatro columnas sosteniendo un balcón central. Todo era moderno y no había ni una sola referencia historicista. Finalmente, al ser cedidos los restos monumentales al obispado, se cambió el proyecto $\mathrm{y}$ se forró toda la fachada principal del hospital con los materiales provenientes del palacio, encargándose Torbado del traslado del monumento, en lo que parece ya una especialización.

La modificación para adaptar al nuevo edificio diseñado los restos barrocos sólo hizo cambiar el diseño de la entrada principal, donde se acopló la grandiosa portada de la mansión de los Prado, y forrar los muros con los sillares traídos del palacio. El resto no varió estructuralmente en nada, ni en planta ni en alzado se hicieron cambios considerables a pesar de la metamorfosis. Sillares, columnas, escudos y demás elementos arquitectónicos se dispusieron sobre el edificio proyectado, como si fuera una segunda piel adherida al edificio funcional, haciendole parecer lo que nunca fue. Lo que lamentablemente sí se alteró fue la composición original del palacio, trastocada para siempre en su estructura, como sucedía en estos casos, con el fin de servir a los intereses de un edificio que no fue pensado para tener semejantes galas. Pueden valer como ejemplos la distinta ubicación de vanos, las variaciones en la línea de los muros, o la drástica modificación de las proporciones de la portada principal, más esbelta y con mayor carácter manierista en su enclave original ${ }^{99}$.

\footnotetext{
${ }^{99}$ En la clave de la puerta se sustituyó el escudo de los Prado por el escudo del obispo Almarcha, que analiza Cimadevilla SÁNCHEZ, P. ob. cit., pp. 472-473.
} 
El traslado del monumento se hizo contraviniendo los criterios y la legislación de la época, para reinventar un "monumento" en el que se encaja lo que sirve y el resto se abandona o se reubica fuera de contexto $^{100}$. Actuando así se perpetra un falso histórico con el pretexto de salvar unos restos legendarios. Tampoco en esta ocasión se documenta la restauración explicando las alteraciones producidas ni diferenciando lo recreado subjetivamente. Más bien al contrario; se aprovecha su ubicación en el casco histórico para presentarle como si fuera un palacio auténtico.

${ }^{100}$ AA.VV., León. Guía de arquitectura..., p. 73 


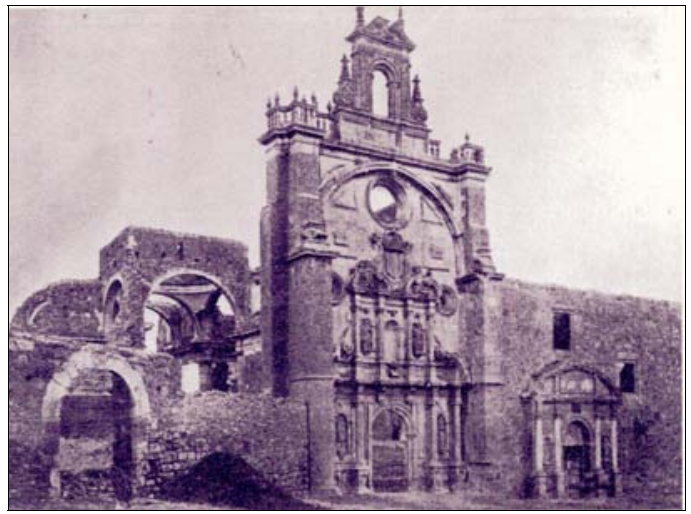

- Fig.1. Vista del monasterio de Eslonza antes de su traslado (colección particular) (arriba izda)

- Fig.2. Alzado para la parroquia de Renueva (proyecto de J. Torbado, A. COAL, exped. 42.214) (arriba dcha)

- Fig.3. Vista actual de la parroquia de Renueva (abajo centro)
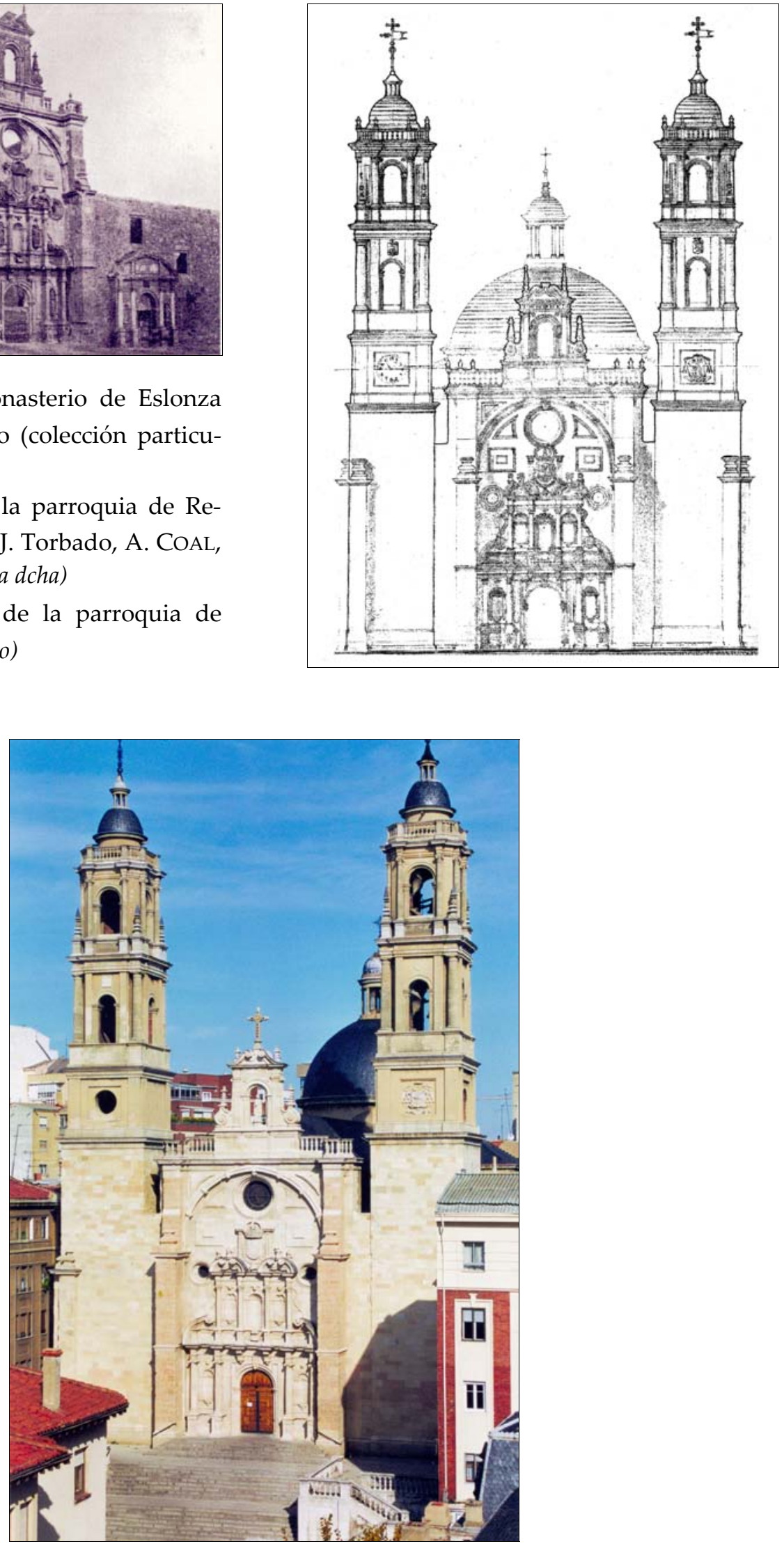


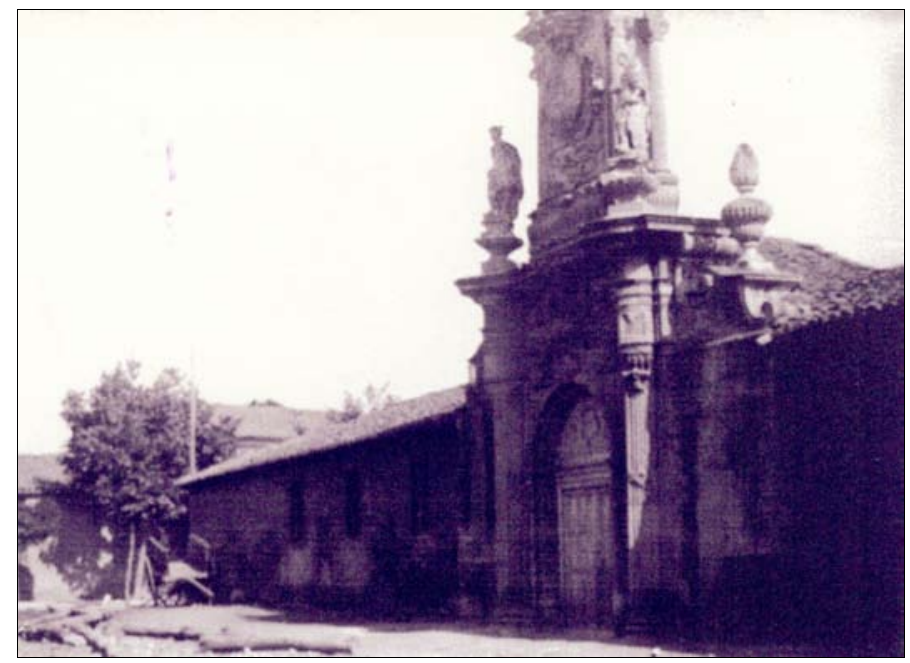

- Fig.4. Vista de la fábrica de hilados antes del traslado (Foto del Instituto Leonés de Cultura)

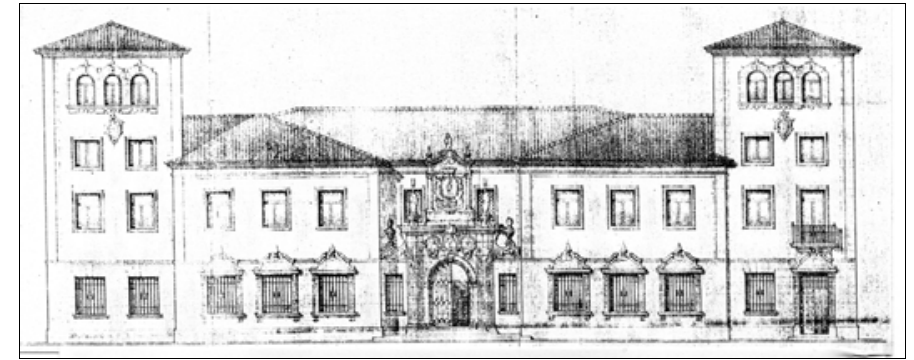

- Fig.5. Proyecto de J. Barroso para la Audiencia de León (A. Gral de Adm. del M. de Justicia, caja 87/76)

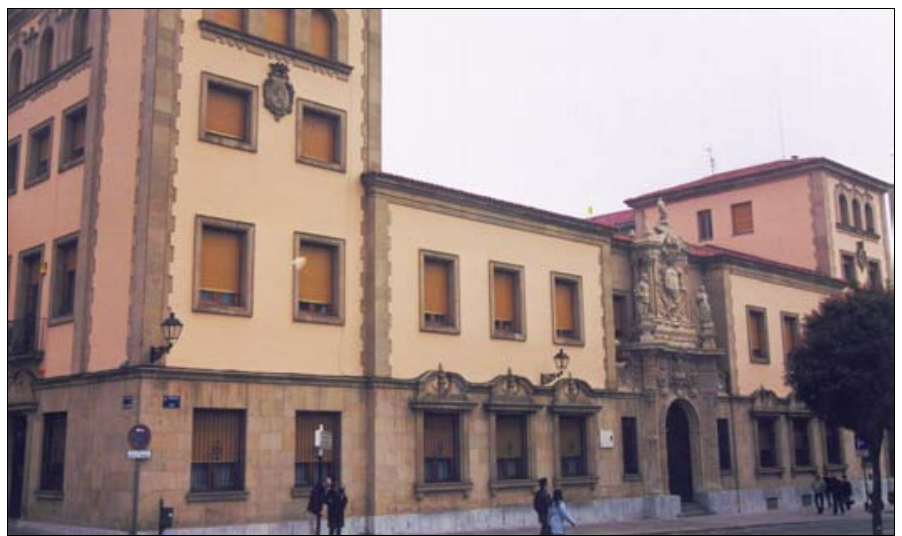

- Fig.6. Vista de la Audiencia Provincial de León 


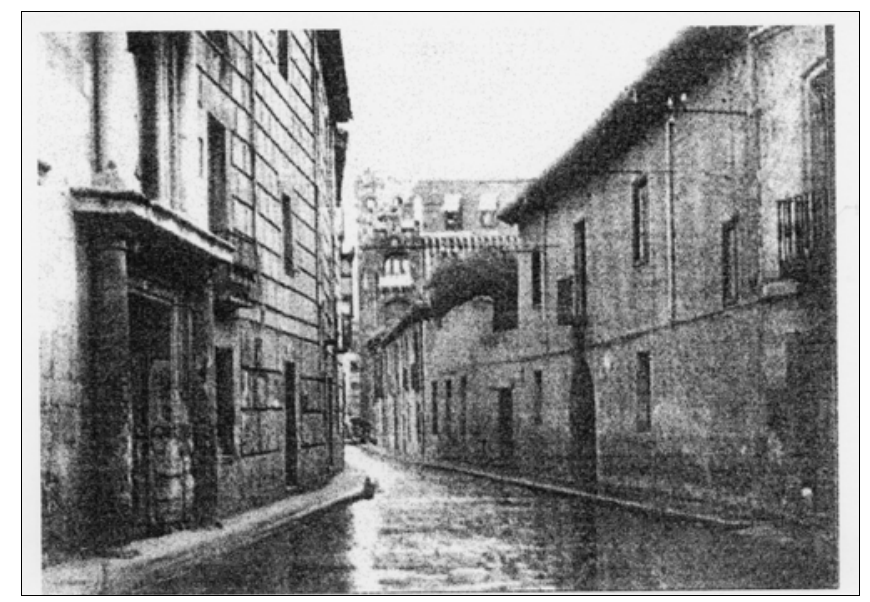

- Fig.7. A la izquierda, detalle de la casa de Quirós antes de su desmantelamiento (Colección particular)

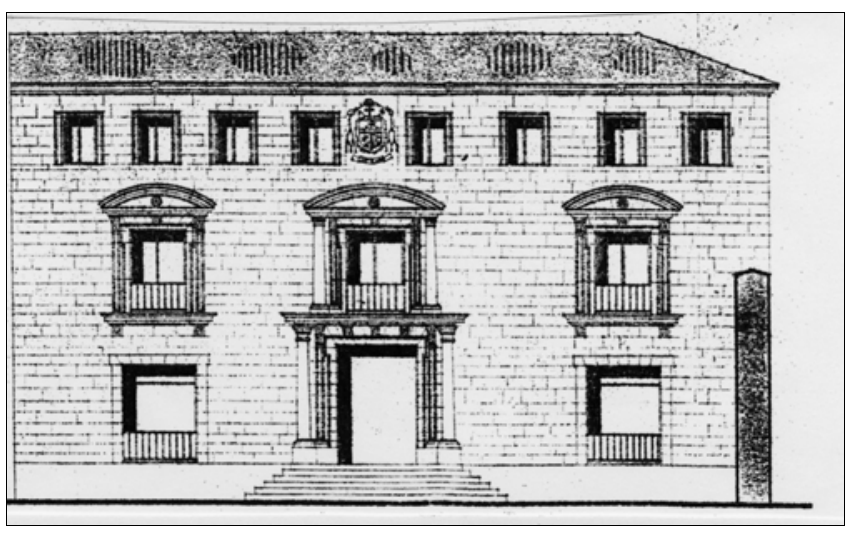

- Fig.8. Proyecto de J. Torbado para la fachada de la Escuela de Arte Sacro (A. COAL, Expediente 42.542)

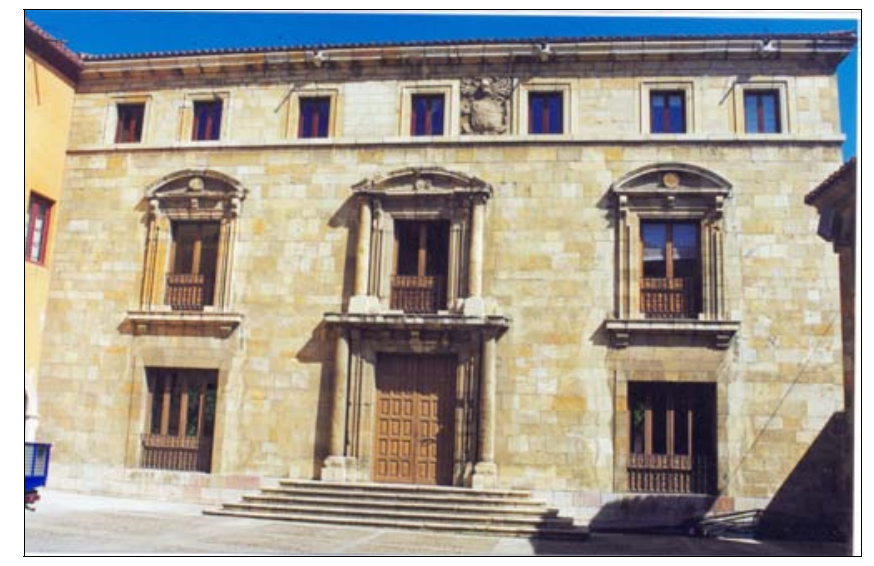

- Fig.9. Vista actual de la antigua Escuela Superior de Arte Sacro 


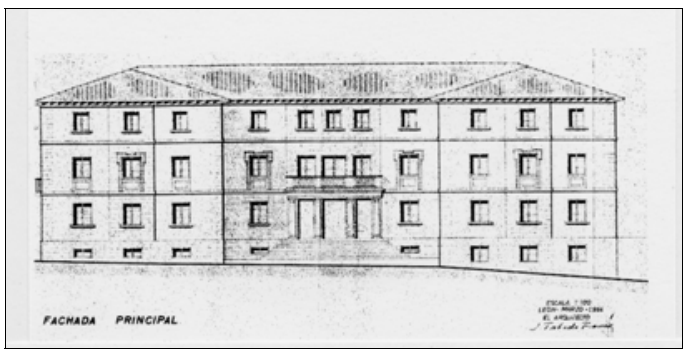

- Fig.10. Proyecto de J. Torbado para la Obra Hospitalaria de № $S^{\underline{a}}$ de Regla (A. COAL, Expediente no ${ }^{\circ}$ 42.554) (arriba izda)

- Fig.11. La fachada del palacio de los Prado en su primitivo emplazamiento (Foto: Instituto Leonés de Cultura) (arriba dcha)

- Fig.12. Vista actual de la Obra Hospitalaria N № $S^{\underline{a}}$ de Rega (abajo centro)
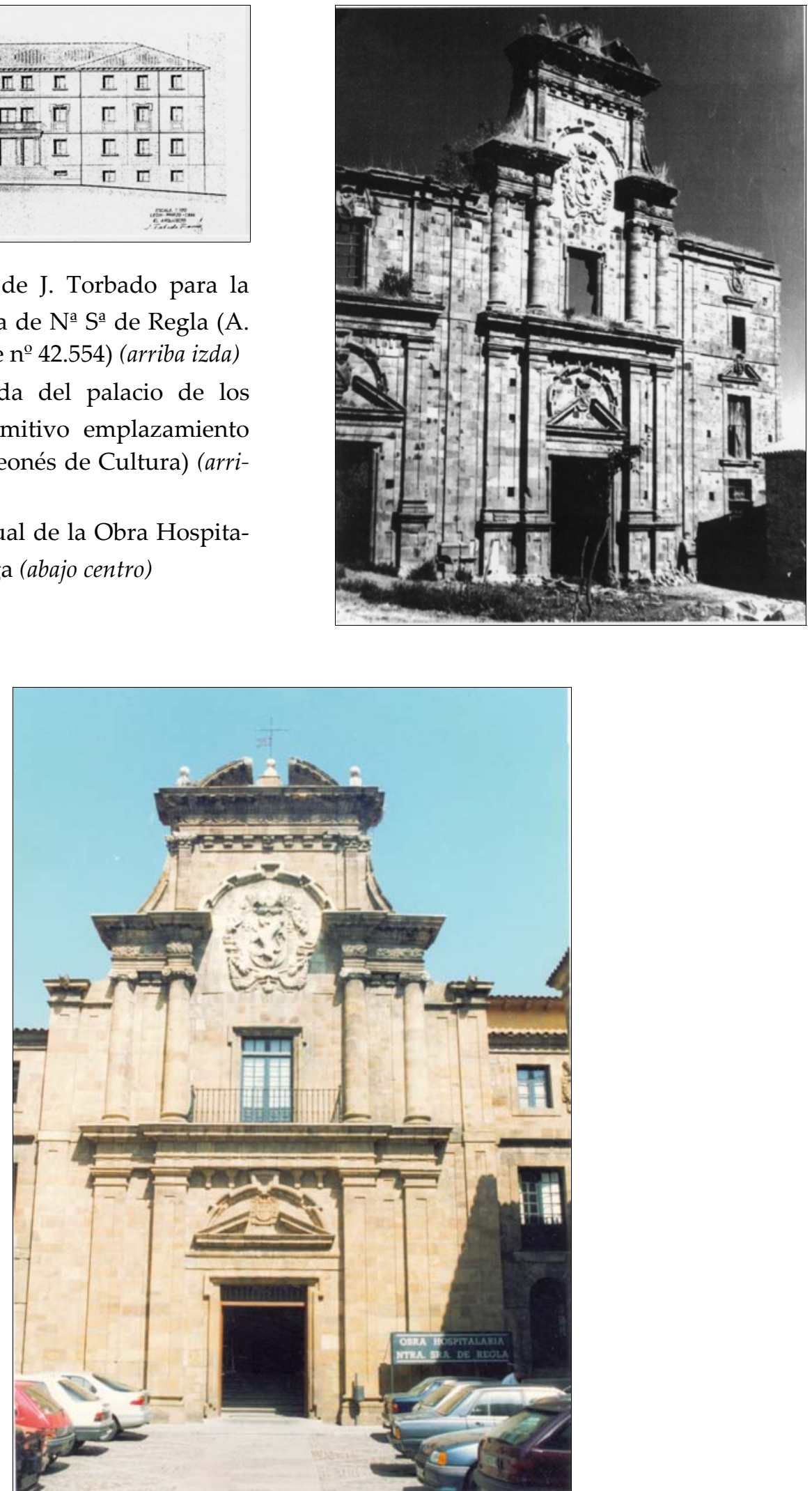